\title{
Accuracy of References in Different Speciality Medical Journals of Nepal
}

\section{P Adhikari R Acharya}

GMS Memorial Academy of ENT and Head and Neck Studies, TU Teaching Hospital, Kathmandu, Nepal.

\section{Correspondence to}

Dr. Prakash Adhikari, GMS Memorial Academy of ENT and Head and Neck Studies, TU Teaching Hospital, Kathmandu, Nepal.

Email: drprakashadhikari@hotmail.com

Objective:

This study was undertaken to find out the accuracy of references in different speciality medical journals of Nepal.

\section{Materials and methods:}

Out of 7 speciality journals of Nepal, 90 references were randomly selected from Journal of Nepal Paediatric Society, Nepal Journal of Obstetrics and Gynaecology and Nepalese Journal of Ophthalmology. Thirty references were chosen from volume 30, number 1 and 2, 2010 issue of Journal of Nepal Paediatric Society; volume 4, number 1, 2009 issue of Journal of Obstetrics and Gynaecology; Volume 2, issue 4, Number 2, 2010 issue of Nepalese Journal of Ophthalmology. References were examined in details and checked with the original for accuracy, using six elements. Statistical analysis was done by using frequency and percentage.

\section{Results:}

Results shows that 33.3\% references in Journal of Nepal Paediatric Society, $43.3 \%$ references in Nepal Journal of Obstetrics and Gynaecology, and 50.0\% references in Nepalese Journal of Ophthalmology (in sample journal issues) were incorrect. Most common errors in all these three journals were the name of the journal name and author's name. Errors in one element of references were found in $90.0 \%, 76.9 \%$ and $66.7 \%$ in the randomly collected issues of Journal of Nepal Paediatric Society, Nepal Journal of Obstetrics and Gynaecology and Nepalese Journal of Ophthalmology respectively.

Conclusion:

Errors in citing the references are found in different speciality medical journals of Nepal. The majority of errors are can be avoided if the authors, editors and the reviewers become cautious about it before publication.

Keywords:

References, accuracy, speciality medical journals.

\section{INTRODUCTION:}

References in a scientific publication are the source of information for the readers. It helps the readers, reviewers and editors to easily locate the publications cited by authors. They serve as an important tool in providing credibility to the published literature and help in retrieval of the cited and related information. To be useful, references need to be cited and quoted correctly. ${ }^{1}$

It is very important for the references to be correct as incorrect references frustrate the reader while searching for related articles. ${ }^{2}$ Despite editorial instructions for checking the references accurately before a manuscript submission for publication and availability of various electronic resources, this continues as a major problem in almost all the specialty journals. It is primarily the responsibility of authors to check the references against the original documents and to format these according to the guidelines given by the journal when submitting manuscript. A good scientific journal needs to be accurate in references cited, moreover it is the right of the reader to be facilitated by providing accurate references and hence it becomes the shared responsibility of the contributors and editorial board. 3

The errors in citations of medical journals were first identified in 1950 4 and after that many studies have evaluated the accuracy of references in the published medical journals (general and speciality) in other countries, which reported error rates ranging from $3 \%$ to $60 \% .1,5,6$ Nevertheless, no similar studies have been conducted in Nepal regarding the accuracy of references of specialty medical journals of Nepal. So, this study was undertaken to find out the accuracy of references in different specialist journals of Nepal.

\section{MATERIAL AND METHODS:}

Out of 7 speciality journals of Nepal, 90 references were randomly selected from Journal of Nepal Paediatric Society, Nepal Journal of Obstetrics and Gynaecology and Nepalese Journal of Ophthalmology. Thirty references were chosen from volume 30, number 1 and 2, 2010 issue of Journal of Nepal Paediatric Society; volume 4, number 1, 2009 issue of Journal of Obstetrics and Gynaecology; Volume 2, issue 4, Number 2, 2010 issue of Nepalese Journal of Ophthalmology. The instructions for authors of all these journals were checked carefully. References from Journal of Surgical Society of Nepal, Nepal Journal of Neuroscience and The Nepalese Journal of Psychiatry were not studied. All these journals have not updated their websites so that article could not be retrieved. Regarding Nepalese Journal of ENT and Head and Neck Surgery, it has published only the first issue till now.
So, this journal was also excluded from the study. To the best of our knowledge, on extensive search on the internet, we could not find any journals of other specialty in Nepal. References were examined in details and compared them with the original for accuracy, using the following six elements: authors; including spelling, initials, order and number; title, including spelling and punctuation; journal name, including use of correct abbreviation as listed in Index Medicus; year; volume; and page numbers, including first and last page numbers. Citations were considered incorrect if there was an error in any of these six elements. When there is more than one error, it is counted as one but a multiple error. References not cited from indexed journals were excluded. References from book citation, chapter citation, electronic citation and article in press were excluded. Statistical analysis was done by using frequency and percentage.

\section{RESULTS:}

Results shows that $33.3 \%$ references in Journal of Nepal Paediatric Society, $43.3 \%$ references in Nepal Journal of Obstetrics and Gynaecology, and $50.0 \%$ references in Nepalese Journal of Ophthalmology were incorrect. Most common errors in all these three journals were journal name and author's name. Journal name was found to be incorrect in $16.7 \%$ in Journal of Nepal Paediatric Society, $13.30 \%$ in Nepal Journal of Obstetrics and Gynaecology and $23.4 \%$ in Nepalese Journal of Ophthalmology. Least common errors in citing references in all these journals were the year and volume number (Table 1). Errors in one element were found in $90.0 \%, 76.9 \%$ and $66.7 \%$ in Journal of Nepal Paediatric Society, Nepal Journal of Obstetrics and Gynaecology and Nepalese Journal of Ophthalmology respectively

\begin{tabular}{|l|c|c|c|}
\hline \multicolumn{1}{|c|}{$\begin{array}{c}\text { Table: 1. Frequency of reference errors in specialty medical journals } \\
\text { Errors }\end{array}$} & $\begin{array}{c}\text { Journal of Nepal } \\
\text { Paediatric Society } \\
\text { Number } \\
\text { (Percentage) }\end{array}$ & $\begin{array}{c}\text { Nepal Journal of } \\
\text { Obstetrics and } \\
\text { Gynaecology } \\
\text { Number } \\
\text { (Percentage) }\end{array}$ & $\begin{array}{c}\text { Nepalese Journal } \\
\text { of Ophthalmology } \\
\text { Number } \\
\text { (Percentage) }\end{array}$ \\
\hline Author's name & $4(13.3 \%)$ & $4(13.3 \%)$ & $4(13.3 \%)$ \\
\hline Title & 0 & $2(6.7 \%)$ & $1(3.3 \%)$ \\
\hline Journal Name & $5(16.7 \%)$ & $4(13.3 \%)$ & $7(23.4 \%)$ \\
\hline Year & $*$ & $*$ & $*$ \\
\hline Volume number & $*$ & $1 *(3.3 \%)$ & $1^{*}(3.3 \%)$ \\
\hline Page number & $1 *(3.3 \%)$ & $2(6.7 \%)$ & $2 *(6.7 \%)$ \\
\hline Total error & $10(33.3 \%)$ & $13(43.3 \%)$ & $15(50.0 \%)$. \\
\hline
\end{tabular}

$\left.{ }^{*}\right)$ indicates that there was error in that component but it is multiple error and is counted in other element 


\begin{tabular}{|l|c|c|c|}
\hline \multicolumn{4}{|c|}{ Table: 2 Types of error in quoting the references } \\
\hline $\begin{array}{l}\text { Journal/ } \\
\text { Types of errors }\end{array}$ & $\begin{array}{l}\text { Error in one } \\
\text { elements }\end{array}$ & $\begin{array}{l}\text { Error in two } \\
\text { elements }\end{array}$ & $\begin{array}{l}\text { Error in more } \\
\text { than two elements }\end{array}$ \\
\hline $\begin{array}{l}\text { Journal of Nepal } \\
\text { Paediatric Society }\end{array}$ & $9(90.0 \%)$ & 0 & $1(10.0 \%)$ \\
\hline $\begin{array}{l}\text { Nepal Journal of } \\
\text { Obstetrics and } \\
\text { Gynaecology }\end{array}$ & $10(10.0 \%)$ & $2(15.4 \%)$ & $1(7.7 \%)$ \\
\hline $\begin{array}{l}\text { Nepalese Journal } \\
\text { of Ophthalmology }\end{array}$ & $10(66.7 \%)$ & $3(20.0 \%)$ & $2(13.3 \%)$ \\
\hline
\end{tabular}

Table: 3. Examples in citing the references in speciality medical journals

The corrected one is indicated by bold letters [1- uncorrected one and 2-corrected one]

\section{Journal of Nepal Paediatric Society}

\section{Author's name error}

1. Maisles MJ,Balter RD,Bhutani V,et.al. Management of hyperbilirubinemia in the newborn infant 35 or more weeks of gestation. Pediatr.2004; 114:297-316.

2. American Academy of Pediatrics Subcommittee on Hyperbilirubinemia. Management of hyperbilirubinemia in the newborn infant 35 or more weeks of gestation. Pediatr.2004; 114: 297-316.

\section{Journal name spelling error}

1. Clarkson JE, Cowan JO, and Herbison GP. Jaundice in full term healthy neonates: A population study. Aust Pediatr J 1984; 20:3038.

2. Clarkson JE, Cowan JO, and Herbison GP. Jaundice in full term healthy neonates: A population study. Aust Paediatr J 1984; 20: 303-8.

Page number error (also author's name and Journal name error)

1. Westake S, Cooper N, Rachet B, Coleman MP. Survival from cancers of the kidney and ureter in England and Wales up to 2001. British journal of cancer 2008;99:593-5.

2. Westlake S, Cooper N, Rachet B, Coleman MP. Survival from cancers of the kidney and ureter in England and Wales up to 2001. Br J Cancer 2008 Sep 23; 99 Suppl 1: S93-5.

\section{Nepal Journal of Obstetrics and Gynaecology}

Author's name error

1. Rose P, Lappas P. Analysis of the cost effectiveness of concurrent cisplatin-based chemo-radiation in cervical cancer: implications from five randomized trials. Gynecol Oncol 2000; 78: 3-6.

2. Rose P, Lappas PT. Analysis of the cost effectiveness of concurrent cisplatin-based chemo-radiation in cervical cancer: implications from five randomized trials. Gynecol Oncol 2000; 78: 3-6.

\section{Article title error (also journal name error)}

1. Kulkarni JN, Mistry RC, Kamat MR, Chinoy R, Lotlikar RG. Case report of autonomous aldosterone-secreting ovarian tumour Gynaecologic Pathology 1990; 37:284-9.

2. Kulkarni JN, Mistry RC, Kamat MR, Chinoy R, Lotlikar RG. Autonomous aldosterone-secreting ovarian tumour. Gynaecol Oncol 1990; 37: 284-9.

\section{Page number error}

1. Adeyemi SD, Grange AO, Giwa-Osagie OF, Elesha SO. Adrenal rest tumor of the ovary associated with isosexual precocious pseudopuberty and cushingoid features. Eur J Pediatr 1986; 145: 236.

2. Adeyemi SD, Grange AO, Giwa-Osagie OF, Elesha SO. Adrenal rest tumor of the ovary associated with isosexual precocious pseudopuberty and cushingoid features. Eur J Pediatr 1986; 145: 236-238.
Journal name, year, volume number and page number error

1. Tsai HJ, Chen SC, Wei HY, Chen GD. Hypothyroidism and Hyperlipidemia with a Virilizing Ovarian steroid cell tumor, Not Otherwise Specified.

2. Tsai HJ, Chen SC, Wei HY, Chen GD. Hypothyroidism and Hyperlipidemia with a Virilizing Ovarian steroid cell tumor, Not Otherwise Specified. Gynecol Endocrinol 2007; 23(2): 69-71.

\section{Nepalese Journal of Ophthalmology}

\section{Page number error}

1. Khosravl AD, Mehdinejad M and Heldari M (2007) Bacteriological findings in patients with ocular infection and artibiotic susceptibility patterns ofisolated pathogens. Singapore Med J;48(8):741.

2. Khosravl AD, Mehdinejad M and Heldari M (2007) Bacteriological findings in patients with ocular infection and artibiotic susceptibility patterns ofisolated pathogens. Singapore Med J; 48(8): 741-743.

\section{Journal name error}

1. Wahab S, Mahmood N, Shaikh Z, Kazmi WH.J (2008). Frequency of retinopathy in newly diagnosed type 2 diabetes patients. Pak Med Assoc; 58(10):557-61.

2. Wahab S, Mahmood N, Shaikh Z, Kazmi WH.J (2008). Frequency of retinopathy in newly diagnosed type 2 diabetes patients. Pak Med Assoc J ; 58(10):557-61.

\section{Missing 4th author}

1. Silver J, Gilbert CE, Spoerer P (1995). Low vision in east African blind school students: need for optical low vision services. Br J Ophthalmol; 79:814-820.

2. Silver J, Gilbert CE, Spoerer P, Foster A (1995). Low vision in east African blind school students: need for optical low vision services. Br J Ophthalmol; 79:814-820.

(Table-2). Some of the examples of errors in citing the references in each of the four journals are given in Table-3.

DISCUSSION:

List of references are very important part of any publication. This is so because the cited references form the basis on which the reported work intends to build on. Therefore, cited references must be correct. Unfortunately, cited references have been found to be inaccurate in every journal in which they have been examined, in this study. Most medical journals follow the "Uniform Requirements for Manuscripts Submitted to Biomedical Journals," which follow the Vancouver style for formatting references. The requirements specify that authors are expected to check the accuracy of references against the original article. Accurate references allow interested readers to easily locate additional publications that are relevant to the subject of a specific journal article. To easily retrieve the cited article easily, the accurate reference, i.e. the journal title, the year of publication, volume number, and page number, is essential.

Correct references gives credit to the original researchers and allows readers to easily retrieve cited articles. 7,8 The ethics of high quality research methods have been eloquently documented elsewhere and clearly state that accurate referencing is part of a good research practice. ${ }^{9}$ References can often be traced back over several publications in which they were previously incorrectly cited- the error then becoming repetitious. This may be evidence of authors having drawn incorrect conclusions from another source without even examining the original context of the citation.

Previous investigators have reported on reference accuracy in various general and speciality biomedical journals and found error rates ranging from $3 \%$ to $60 \% .6-11$ High error rates $(4.1 \%-40.3 \%)$ were even found among leading biomedical journals that check references prior to publication. 12 Most errors affect the names of authors, followed by errors in the title element of a reference. ${ }^{8-11}$

The present study revealed that $33.3 \%$ of the references in Journal of Nepal Paediatric Society were incorrect. The error rate in different pediatric journals has been found to vary from 29 to 39\%.6,1 There 
was $43.3 \%$ error in citing the references in Nepal Journal of Obstetrics and Gynaecology which is higher than the study done by Roach et al. 13 His study showed that Australian and New Zealand Journal of Obstetrics and Gynaecology and British Journal of Obstetrics and Gynaecology have got inaccuracies in references in $55.6 \%$ and $66.7 \%$ respectively. Similarly, in Nepalese Journal of Ophthalmology there was $50.0 \%$ error in citing the references which is higher than the study done by Buchan et al.14

Errors in the author's name may only demonstrate a lack of attention to detail. However, the names of authors are not only critical for retrieving articles but are also relevant when author citations are used to measure research productivity. The majority of errors were spelling mistakes in authors' names or in the title. These errors would not make it difficult to retrieve the cited article. However, if the cited reference contains an error in a critical element of the reference, this would make it more difficult for the reader or a librarian to retrieve the article. Our study revealed that most common errors in citing the references were journal name and author's name which is similar to the study done in indexed journals of Nepal. 15 Similarly, majority of errors were in only one element out of six elements.

Probable causes of errors in references may include oversight, rush to publish, or the creating of pressure by believing in the concept of 'publish or perish'.16 However, these reasons hardly justify the presence of errors. Despite the persistent problem of reference errors, no effective solutions appear to have emerged. Although it may be impossible to develop a foolproof system that ensures reference accuracy, checks can be performed at the following points: the authors, the editors, and the referees. 15

Various suggestions have been given to reduce the inaccuracy in references. Vargas-Origel et al 6 suggested limiting the number of references and submission of the first page of the article cited to verify the reference. Study of Eichorn and Yankauer 5 had earlier observed increased error rates with increased number of references. However, subsequently other studies established that the error rate is independent of the number of references. 17,18 On the contrary, limiting the number of references might force the authors to omit some important references. Submission of the first page of the cited article is desired by some journals like Canadian Journal of Anesthesia but in a study conducted by McLellan et al. 19 number of errors in Canadian Journal of Anesthesia was similar to that in other Journals. We could not ascertain whether the requirement of first page of the cited article was practiced before the study or introduced later.

\section{CONCLUSION:}

Errors in citing the references are also found in different specialty medical journals of Nepal, Nepalese Journal of Ophthalmology citing the highest percentage of errors. The results of all these three journals are comparable with international speciality medical journals. The majority of errors are avoidable. So, the authors, editors and the reviewers have to check for any errors seriously before publication in the journal.

\section{REFERENCES:}

1. Gupta P, Yadav M, Mohta A, Choudhury P. References in Indian Pediatrics: authors need to be accurate. Indian Pediatr 2005; 42: 140-5.

2. Mohta A, Mohta M. Accuracy of references in Indian Journal of Surgery. Indian J Surg 2003; 65: 156-8.

3. Aronsky D, Ransom J, Robinson K. Accuracy of references in five biomedical infomatics journals. J Am Med Inform Assoc 2005; 12: 225-8.

4. Kronick DA. Literature citations, clinico-pathological study, with presentation of three cases. Bull Med Lib Assoc 1958; 46: 291-3.

5. Eichorn P, Yankauer A. Do authors check their references? A survey of accuracy of references in three public health journals. Am J Public Health 1987; 77: 1011-2.

6. Vargas-Origel A, Gomez-Martinez G, Vargas-Nieto MA. The accuracy of references in paediatric journals. Arch Dis Child 2001; 85: 497-8.

7. Raja UY, Cooper JG. How accurate are the references in Emergency Medical Journal? Emerg Med J 2006; 23: 625-6.

8. Orlin W, Pehling J, Pogrel MA. Do authors check their references? A survey of 500 references from the Journal of Oral and Maxillofacial Surgery. J Oral Maxillofac Surg 1996; 54: 200-2.

9. Biebuyck JF. Concerning the ethics and accuracy of scientific citations. Anesthesiology 1992; 77: 1-2.

10. Siebers R. Accuracy of references in the New Zealand Journal of Medical Laboratory Science. N Z J Med Lab Science 1999; 53: 468.

11. Siebers R. How accurate are references in clinical chemistry? Clin Chem 2001; 47: 606-7.

12. Siebers R, Holt $\mathrm{S}$. Accuracy of references in five leading medical journals. Lancet 2000; 356: 1445.

13. Roach VJ, Lau TK, Ngan Kee WD. The quality of citations in major international obstetrics and gynecology journals. Am J Obstet Gynecol 1997; 177: 973-5.

14. Buchan JC, Norris J, Kuper H. Accuracy of referencing in the ophthalmic literature. Am J Ophthalmol 2005; 140: 1146-8.

15. Adhikari P. Accuracy of references in indexed journals of Nepal. Nepal Med Coll J 2009; 11: 130-2.

16. Singh S, Chaudhary R. Accuracy of references cited in articles published in Indian Journal of Dermatology, Venereology and Leprology: a pilot study. Indian J Dermatol Venereol Leprol 2009; 75: 488-91.

17. Evans JT, Nadjari HI, Burchell SA. Quotational and reference accuracy in surgical journals. A continuing peer review problem. J Am Med Assoc 1990; 263:1353-4.

18. George PM, Robbins K. Reference accuracy in the dermatologic literature. J Am Acad Dermatol 1994; 31: 61-4.

19. McLellan MF, Case LD, Barnett MC. Trust but verify. The accuracy of references in four anesthesia journals. Anesthesiology 1992; 77: $185-8$. 